Милан П. Миликић

Ненад Р. Вуловић

Александра М. Михајловић

Универзитет у Крагујевцу

Факултет педагошких наука у Јагодини

Катедра за дидактичко-методичке науке
УДК 371.3::511.13:004.4

https://doi.org/10.18485/uzdanica.2020.17.1.19

Оригинални научни рад

Примљен: 10. фебруар 2020.

Прихваћен: 11. мај 2020.

\title{
ГЕОМЕТРИЈСКА ИНТЕРПРЕТАЦИЈА РАЗЛОМАКА ПРИМЕНОМ ОБРАЗОВНОГ СОФТВЕРА ГЕОГЕБРА
}

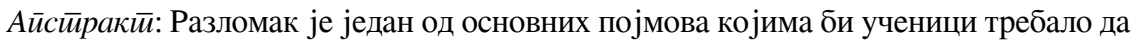
овладају у оквиру наставе математике у млађим разредима основне школе. С обзиром на ниво развијености когнитивних структура ученика овог узраста и потребу за очигледном наставом, вишеструке визуелне репрезентације доприносе бољем разумевању и схватању појма разломка. У првом делу рада бавили смо се приказом конкретних примера поделе целине на половине уз коришћење софтвера ГеоГебра, док смо у другом делу анализирали резултате истраживања спроведеног са циљем одређивања степена заступљености образовног софтвера у настави математике у нижим разредима основне школе и ставова учитеља према њему. Узорак истраживања чинило је 108 учитеља са територије Републике Србије. Резултати указују да за велики проценат испитаника образовни софтвер представља терминолошки недовољно разјашњен појам. Резултати су такође показали да, иако већина испитаника сматра да образовни софтвер доприноси повећању квалитета знања ученика, веома мали део њих га је и користио у настави математике, а образовни софтвер ГеоГебра, који је у фокусу нашег рада, представља непознаницу за већи део испитаника, иако сви који су га користили имају позитиван став у погледу његове корисности и функционалности у настави математике.

Кључне речи: образовни софтвер, ГеоГебра, разломци, половина, учитељи.

\section{УВОД}

Деца се од најранијег доба свог живота у свакодневним ситуацијама сусрећу са различитим начинима поделе целине на делове. Желећи да целину (храну, играчке, новац) поделе на више делова (са другом, пријатељима, породицом), поделу врше трудећи се да приликом деобе добију делове приближно једнаке по маси и облику. Како су то најчешће једине битне карактеристике поделе, можемо говорити о подели на половине, трећине, четвртине, итд. На тај начин, деца се спонтано по први пут сусрећу са појмом разломка.

Разломци се сматрају једним од основних појмова којима ученици, поред аритметичких правила, треба да овладају у разредној настави (Там- 
би, Еу 2013). Уважавајући ниво когнитивног развоја ученика, упознавање са појмом разломка мора тећи спонтано и ићи од конкретног ка апстрактном. У складу са тим, ученици се упознају са појмом разломка коришћењем конкретних примера са пицом, оловкама, столицама и слично (Ву 2011), док касније модели постају апстрактнији и динамичнији.

Појам разломка сложен је за разумевање. Учење разломака није довољно ефикасно и представља потешкоћу у математичком образовању за велики број ученика (Турлингс, Купман, Брок, Пепин 2019). Разлог томе је што је скуп природних бројева основни скуп који карактерише наставу математике у првом циклусу образовања, а са скупом рационалних бројева се упознају у другом циклусу. Ученици су навикнути на интуитивне методе учења које примењују на елементе скупа природних бројева користећи четири основне аритметичке операције. Овакве методе нису применљиве на разломке, што и јесте један од разлога због чега ученици сматрају разломке тешким за разумевање (МекНамара, Шонеси 2010, видети: Булут и др. 2015; Ван Стинбруге 2012; Фу Лок, Ху Тонг, Таи Чау 2017). Додатном неразумевању појма и особина разломака доприноси исувише учестало једнолично представљање разломака, па је потребно упознати ученике са различитим начинима репрезентације разломака. С обзиром на то да се ученици млађег основношколског узраста налазе на нивоу конкретног мишљења, вишеструке визуелне репрезентације разломака доприносе активацији процеса учења, чине наставни садржај разумљивијим и подстичу формирање функционалног знања (Булут и др. 2015; Лазић, Маричић, Милинковић 2015).

Развој појма разломка применом традиционалног приступа настави уз употребу недоследних наставних средстава може збунити ученике. Уџбеници који су у употреби дају дводимензионални приказ разломка, нединамични су и одликује их статичан приказ разломака (Гудвин 2008). У наставним програмима као главни циљ првенствено се истиче овладавање извођењем рачунских операција са разломцима. У наставним програмима математике већине земаља као главни циљ првенствено се истиче овладавање извођењем рачунских операција са разломцима.

У Србији, извођење рачунских операција са разломцима представља садржај који се изучава у старијим разредима основне школе. По новом програму наставе и учења за четврти разред основне школе предвиђено је да ученици врше сабирање и одузимање разломака са једнаким имениоцима, али искључиво ослањајући се на одговарајућу визуелну репрезентацију. Пре тога, веома је важно ученицима дати прилику да разумеју појам разломка и као крајњи циљ - да размишљају пропорционално (Кларк, Рош, Мичел 2011). Без јасне представе о релативној природи рационалних бројева није могуће напредовање у даљем математичком образовању (Нуњес и др. 2006). Нуњес и сарадници, такође, сматрају да би требало успоставити одговарајуће везе између дечијег интуитивног схватања појма разломка и процеса конципирања 
наставе о разломцима. Ово је неопходно како би се успоставило адекватније разумевање разломака и ширег домена рационалних бројева јер разломци представљају незаобилазни део у оквиру садржаја алгебре и вероватноће.

Као главне препреке у настави математике, Мајерек наводи да ученици усвајају појмове без адекватних илустрација, настава обилује нединамичним приказима, који не дозвољавају ученицима генерализацију појмова (Мајерек 2014). Тако усвојен појам разломка, са неадекватном репрезентацијом, може инхибирати даље учење математичких садржаја. Насупрот томе, коришћење иновативних динамичких модела омогућава лакше и целисходније разумевање појма разломка (Гудвин 2008; Пун 2017). Софтверски алати за динамичку математику пружају најбоље могућности у дизајнирању таквих визуелних и динамичких модела.

Прва формална знања о разломцима ученици стичу у разредној настави, па је важно да учитељи током наставе пажљиво руководе процесом овладавања овим појмом. Један од ефикасних начина да помогну ученицима који још увек нису разумели појам разломка традиционалним приступом јесте визуелизација. Алат који се може искористити у ту сврху је ГеоГебра (Тамби, Еу 2013). Бројна истраживања истичу визуелизацију као једну од најмоћнијих дидактичких компоненти софтвера ГеоГебра (Лавица 2007; Жилинскиене 2014). Иако није намењен учењу разломака колико учењу садржаја геометрије, он се може применити и на разумевање ових концепата (Џонсон, Брофи 2011). Софтвер нуди динамички приказ различитих модела разломака, омогућавајући тако бољу визуелизацију и за ученике и за учитеље. Пун (Poon 2017) истиче да GeoGebra представља важан наставни алат, зато што ученицима омогућава да визуелизују промене у разломцима приликом варирања различитих фактора (мењање бројиоца, имениоца, увођење еквивалентних разломака итд.). Могући начин употребе овог алата показаћемо на примеру половине.

\section{ПРИМЕРИ ВИШЕСТРУКИХ ИНТЕРПРЕТАЦИЈА ПОЈМА ПОЛОВИНЕ}

Мишљење ученика млађих разреда основне школе је конкретно (Пијаже, видети: Вилотијевић 1999), због чега би учитељи требало да изграде мост између конкретних предмета и суштине појма разломка. На пример, ако су два ученика потрошила по половину новца од џепарца који је сваки од њих двојице имао, то не мора да значи да су потрошили једнаке износе новца (Нуњес и др. 2006).

Представљање разломка кругом представља један од најефикаснијих модела за изградњу менталне слике разломка (Крејмер, Хенри 2002, видети: Лазић, Маричић, Милинковић 2015). Како целину треба поделити на два јед- 
нака дела и то су једине битне особине поменуте целине, важно је да се целина апстрахује, односно искључе могући шумови. Приказ целине у форми круга почиње цртањем произвољне кружнице у ГеоГебри, док је истицањем пречника круг подељен на два једнака дела. Ради једноставнијег уочавања делова пожељно је представити их различитим бојама (Слика 1). Дакле, добијени делови представљају две половине једне целине.

Слика 1. Приказ половина круга у образовном софтверу ГеоГебра

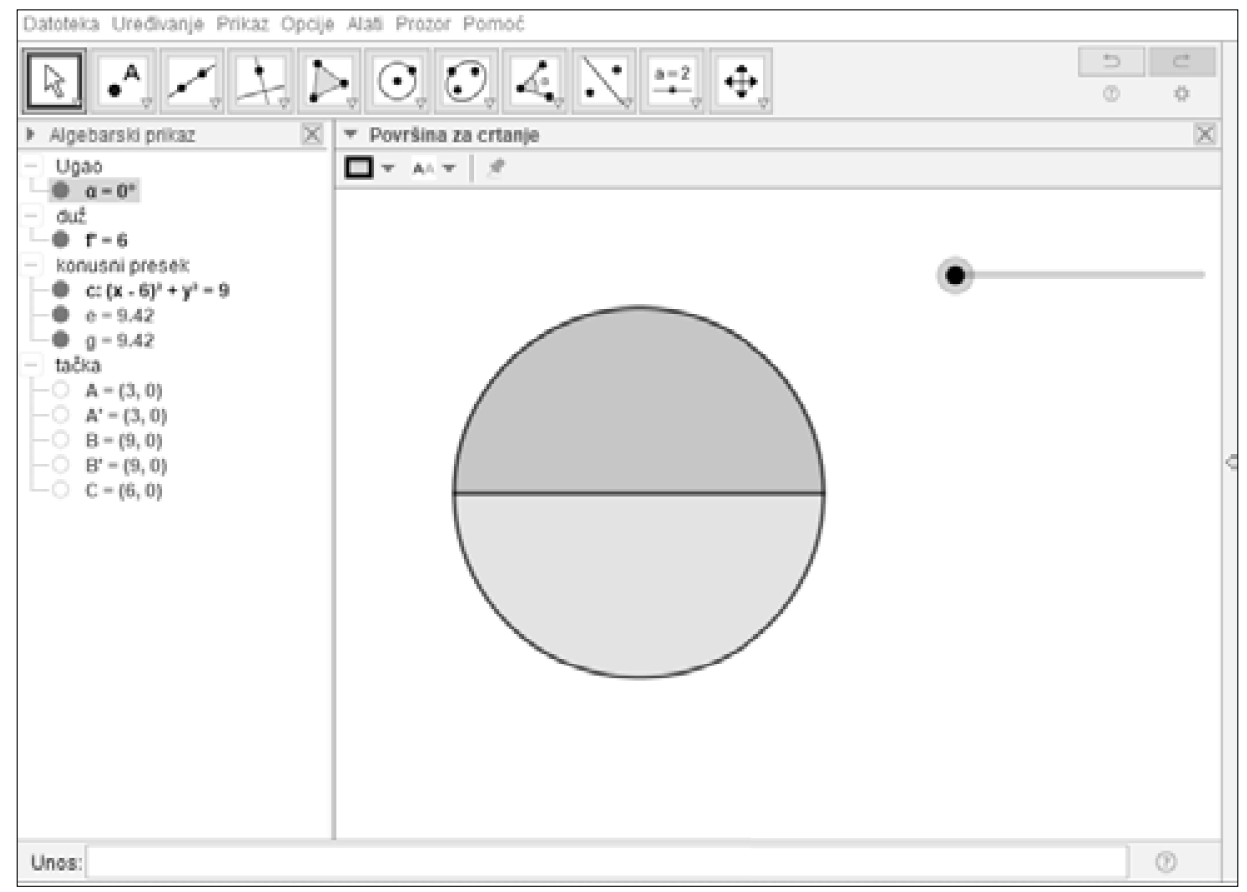

Динамичко манипулисање нацртаним објектима у оквиру овог алата омогућавају нам клизачи чијом изменом вредности можемо пратити промену насталу услед промењене вредности клизача. Увођењем клизача у форми угла од $0^{\circ}$ до $360^{\circ}$ можемо вршити промену положаја пречника који дели дати круг на два једнака дела и тако омогућити вишеструку репрезентацију појма половине. Ученици путем анимације настале променом вредности клизача могу уочити да пречник, у ма ком положају, дели круг на два једнака дела. На Слици 2 дати су неки од могућих приказа поделе целине на половине. 
Слика 2. Могући прикази поделе целине на половине
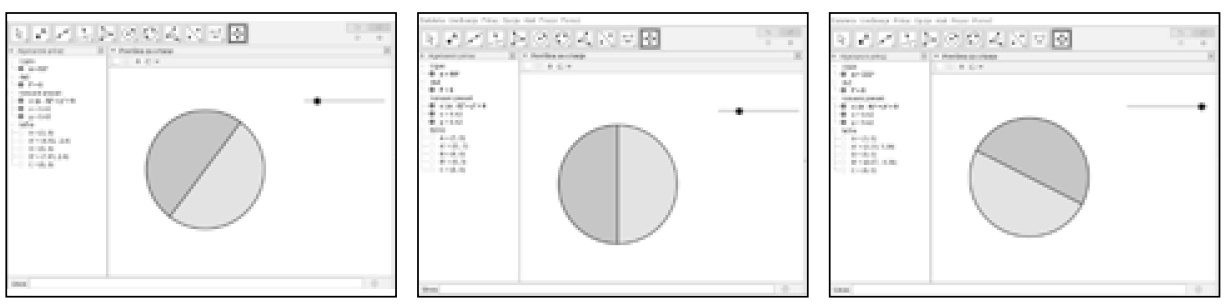

Поред круга, појам половине често се развија и поделом квадрата на два једнака дела. Најзаступљенији примери поделе су путем дијагонала квадрата или помоћу праве која садржи центар описане кружнице и паралелна је једном пару наспрамних страница (Слика 3).

Слика 3. Најзаступљенији примери поделе квадрата на половине
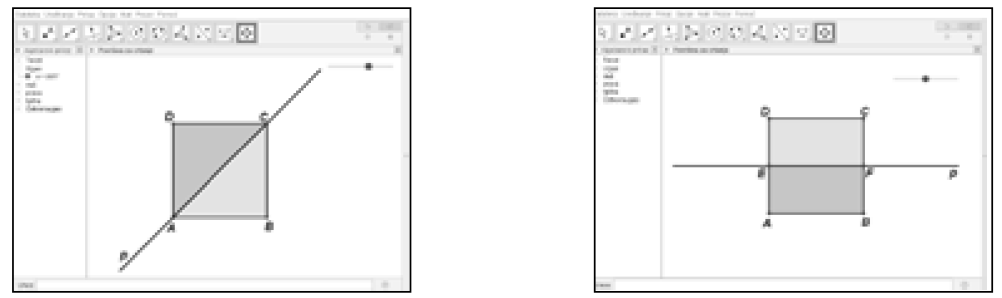

Увођењем клизача у форми угла од $0^{\circ}$ до $360^{\circ}$ који се односи на праву којом вршимо поделу, а која садржи фиксну тачку - центар описане кружнице, може се омогућити увиђање поделе на половине и у случајевима које учитељи не могу класичним начином обраде садржаја прецизно урадити, тј. подела на два подударна правоугла трапеза (Слика 4).

Слика 4. Најзаступљенији примери поделе квадрата на половине
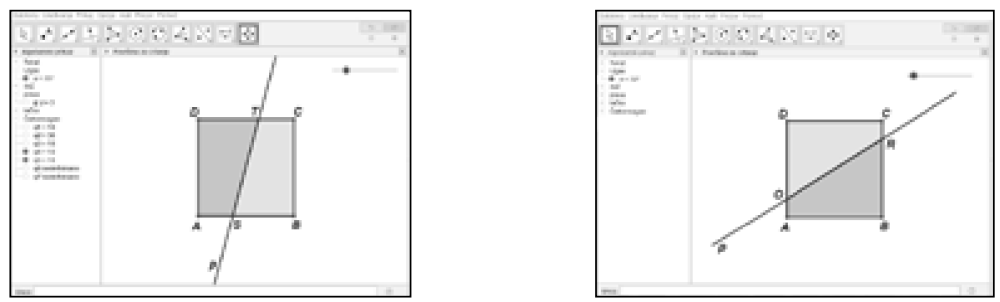

Аналогно поступку поделе квадрата, вршимо деобу целине представљене у облику правоугаоника на половине. Половине могу бити у форми правоугаоника, правоуглих троуглова или правоуглих трапеза. У специјалним случајевима, половине правоугаоника могу бити подударни квадрати. 
Употреба софтвера ГеоГебра у образовне сврхе генерисала је пригодан начин уноса података у природној нотацији, готово истоветно записивању у свесци или на табли, што би рад у ГеоГебри требало да учини једноставним за учитеље. У наставку рада сагледаћемо тренутно стање у погледу применљивости образовног софтвера и ставова учитеља према њему.

\section{МЕТОДОЛОГИЈА ИСТРАЖИВАҢА}

Предмет истраживања које је спроведено за потребе овог рада јесте образовни софтвер у настави математике у млађим разредима основне школе. Циљ истраживања је одређивање степена заступљености образовног софтвера у разредној настави математике и ставова учитеља према њему. У складу са циљем дефинисани су следећи истраживачки задаци којима треба утврдити: у којој мери се користи образовни софтвер у разредној настави математике; ставове учитеља према коришћењу образовног софтвера; тешкоће на које учитељи наилазе приликом обраде садржаја у вези са разломцима; ставове учитеља о могућностима образовног софтвера да превазиђе регистроване проблеме; употребу образовног софтвера ГеоГебра у разредној настави математике.

Узорак истраживања представља 108 учитеља са територије Републике Србије. У узорку је 79,63\% жена и 20,37\% мушкараца. Сви испитаници имају завршено факултетско образовање и радно искуство у наставном процесу. Сви испитаници раде у градским школама. Структура испитаника у односу на дужину радног стажа дата је у Табели 1.

Табела 1. Структура испитаника у односу на радни стаж

\begin{tabular}{lcccc}
\hline & 0-9 година & 10-19 година & 20-29 година & 30 и више година \\
\hline $\begin{array}{l}\text { Заступљеност } \\
\text { испитаника }\end{array}$ & $28,71 \%$ & $19,44 \%$ & $43,52 \%$ & $8,33 \%$ \\
\hline
\end{tabular}

Инструмент истраживања био је упитник који је садржао 16 питања, од којих је 10 питања било затвореног, а 6 отвореног типа. Истраживање је спроведено у октобру 2019. године електронским путем. Сваки испитаник је попуњавао електронски упитник који је био доступан 5 дана.

На основу података добијених истраживањем извршена је статистичка обрада података квалитативном и стандардном квантитативном анализом. Од статистичких мера и поступака коришћени су фреквенције, проценти и табеларно приказивање. 


\section{РЕЗУЛТАТИ И ДИСКУСИЈА}

Образовни софтвер, као део дигиталних технологија које се користе у наставном процесу у разредној настави математике, за учитеље представља терминолошки недовољно разјашњен појам. Под дигиталним технологијама, које су у упитнику дефинисане као све врсте техничких уређаја и софтвера који се користе у наставном процесу, само 13,89\% учитеља регистровало је образовни софтвер као понуђену опцију коју су до сад користили на часовима математике. Примарне дигиталне технологије које су учитељи наводили представљају софтвери за презентације, мобилне апликације са едукативним карактером и образовни видео-материјали. Међутим, дефинисањем образовног софтвера у упитнику као готових компјутерских програма који се користе у настави математике, проценат учитеља који су се изјаснили да су користили образовни софтвер у настави математике увећао се на 54,63\%. Интересантно је да је, након разјашњења овог појма, 26,67\% учитеља који су рекли да користе образовни софтвер у настави математике заправо одговорило да га не користе, док је 51,61\% увидело да користи образовни софтвер иако се иницијално нису одлучили за њега. Употреба образовног софтвера је најмање заступљена у категорији испитаника који имају 30 и више година радног стажа, што је у сагласности са резултатима неких ранијих истраживања (Димитријевић, Поповић, Станић 2012; Радовановић, Карић 2011). Од преосталих категорија, употреба образовног софтвера је најмање заступљена код учитеља који имају мање од 10 година радног стажа. Оваква дистрибуција одговора може сугерисати на потребу веће заступљености и већег степена примене образовног софтвера у иницијалном математичком и методичком образовању учитеља (Димитријевић, Поповић, Станић 2012). У прилог овој констатацији иде и чињеница да је $87,96 \%$ учитеља одговорило да сматра да се применом образовног софтвера у разредној настави математике може повећати квалитет знања ученика. У категорији учитеља који немају овакав став мали је проценат оних који су заправо већ користили неки образовни софтвер. Не постоји нити један специфични образовни софтвер за који се учитељи опредељују као софтвер који ои препоручили колегама. Већина не може да се одлучи, не зна или не би препоручила ниједан софтвер. Недовољна информисаност или неадекватна обученост за коришћење образовног софтвера може представљати разлог оваквог става, што директно може и имплицирати став $41,67 \%$ учитеља који сматрају да коришћење образовног софтвера не може заменити употребу очигледних наставних средстава на часу математике. Испитаници који су навели да су у свом претходном раду примењивали образовни софтвер истичу да га нису користили у великој мери, што је сагласно са неким другим истраживањима (Будински 2013). Њих 59,33\% до сада га је веома ретко примењивало, док 40,67\% с времена на време то чини. Као главни разлози за недовољно коришћење имплицитно 
се наводе недостатак времена, велики број других школских обавеза, недовољна упознатост са одговарајућим софтверима за одређене области, док се у мањој мери истиче и недоступност одговарајућих упутстава на српском језику за одређене функције образовног софтвера.

С обзиром на то да је појам разломка апстрактан за ученике, желели смо да испитамо који су главни проблеми са којима се учитељи срећу приликом реализације ових наставних садржаја. Учитељи као главне садржинске потешкоће које су имали у свом досадашњем раду наводе: отежано разграничавање имениоца и бројиоца, упоређивање нејединичних разломака, одређивање целине на основу задатог дела целине, недовољан број примера графичког одређивања дела задате целине у књигама које користе и примена разломака у текстуалним задацима. Као препрека добром усвајању садржаја о разломцима наводи се и недовољно усвојено извођење рачунских операција у скупу природних бројева. Без обзира на различите врсте проблема са којима се сусрећу, 87,04\% свих испитаника сматра да би применом неког образовног софтвера ученици боље усвајали садржаје везане за разломке.

Образовни софтвер на коме смо се базирали у овом раду је ГеоГебра. Међутим, само 17,59\% испитаника је имало прилику да се упозна са њим и да га користи барем једанпут на часу. Области у оквиру којих су примењивали ГеоГебру су искључиво садржаји геометрије везани за обим и површину геометријских фигура. Сви учитељи који примењују овај образовни софтвер сматрају да он доприноси бољем разумевању садржаја на којима се примењује. Посебно истичу његову једноставност за коришћење, очигледност, прецизност, динамичност приказа и визуелизације, као и корисност у смислу моменталне промене приказа у складу са променом променљивих. Међутим, упркос свим значајним предностима и могућностима које ГеоГебра нуди када су у питању визуелизација, манипулација и испитивање својстава геометријских фигура и математичких појмова, велики број наставника/учитеља има тешкоћа да је користи у свакодневном наставном раду, на шта указују и неки други аутори (Белгеис, Камалуден 2018). Као једини недостатак на коме испитаници у нашем истраживању инсистирају јесте недовољан број готових аплета који се могу примењивати у разредној настави. До сличних резултата - да су учитељи спремни да користе готове аплете, али не и да их креирају указују и истраживања у неким другим земљама (Жилинскиене, Демирбилек 2015). То је последица необавештености, имајући у виду велику базу готових динамичних модела који се могу наћи на на сајту www.geogebra.org и који могу допринети смањењу времена и ресурса потребних за самостално креирање материјала неопходних за извођење наставе математике (Радовић 2013).

Напоменимо да не постоји статистички значајна разлика нити по једном питању у односу на пол испитаника или дужину радног стажа. 


\section{ЗАКЉУЧАК}

Спроведено истраживање показало је да примена образовног софтвера није у великој мери заступљена у разредној настави математике, као и да учитељи нису у довољној мери упознати са различитим образовним софтверима које могу користити. Испитивање примене образовног софтвера ГеоГебра уопште у наставном процесу, а посебно приликом обраде садржаја о разломцима, имало је за циљ регистровање тренутне ситуације у овом сегменту као основе за даље истраживање у коме ће се експериментално утврдити утицај овог образовног софтвера на усвајања знања у вези са разломцима. Примена динамичких математичких софтвера у настави пружа боље могућности у дизајнирању визуелних и динамичких модела. Креирање таквих модела један је од главних задатака софтверског пакета ГеоГебра. Бројна истраживања потврђују чињеницу да примена овог пакета током извођења наставе доприноси да ученици боље разумеју појам разломка (Тамби, Еу 2013; Булут и др. 2015). У овом раду представили смо неколико примера како се применом ГеоГебре може обезбедити вишеструка геометријска репрезентација половине, а у даљим истраживањима утврдићемо тачан ефекат. С обзиром на то да се у другом разреду ученици прво сусрећу са појмом половине, демонстрирали смо начине како се коришћењем ГеоГебре може повећати број примера на којима је могуће уочити половине. У приказаним примерима целине су представљене кругом и квадратом (правоугаоником), будући да су ове геометријске фигуре најподесније за увођење појма половине (Причард 2010).

Захваљујући динамичким променама креираних компоненти које омогућавају образовни софтвери, пред ученицима се могу изводити демонстрације и прикази на основу којих могу изводити даље генерализације. Зато се мора радити на промени ставова учитеља према коришћењу ових софтвера, са циљем правазилажења потешкоћа са којима се сусрећу током њихове употребе. Као полазну тачку у том процесу треба искористити управо позитивна мишљења учитеља у вези са повећањем квалитета знања ученика под утицајем ових софтвера.

\section{ЛИТЕРАТУРА}

Белгеис, Камалуден (2018): Soheila Belgheis, Rosemaliza Kamalludeen, The Intention to Use GeoGebra in the Teaching of Mathematics Among Malaysian Teachers, Malaysian Online Journal of Educational Technology, 6(1), 109-115.

Будински (2013): Natalija Budinski, A survey on use of computers in mathematical education in Serbia, The teaching of mathematics, 16 (1), 42-46.

Булут, Унлутурк Акчакин, Каја, Акчакин (2016): Mehmet Bulut, Hanife Ünlütürk Akçakın, Gürcan Kaya, Veysel Akçakın, The Effects of GeoGebra on Third Grade 
Primary Students' Academic Achievement in Fractions, Mathematics Education, 11(2), 347-355.

Ван Стинбруге (2012): Hendrik Van Steenbrugge, Teaching fractions in elementary school (PhD thesis), Gent: Facilteit Psychologie en Pedagogische Wetenschappen.

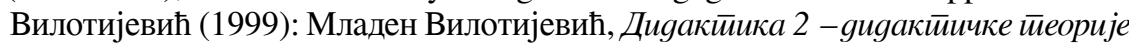
и йеорије учења, Београд: Учитељски факултет.

By (2011): Hung-Hsi Wu, Teaching Fractions According to the Common Core Standards, American Mathematical Society.

Гудвин (2008): Kristy Goodwin, The impact of interactive multimedia on kindergarten students' representations of fractions, Issues in Educational Research, 18(2), 103-117.

Димитријевић, Поповић, Станић, (2012): Slađana Dimitrijević, Branislav Popović, Marija Stanić, Computer use in mathematics teaching - overview of the situation in Serbia, Croatian Journal of Education, 14 (2), 387-415.

Жилинскиене (2014): Inga Žilinskienè, Use of GeoGebra in primary math education: a theoretical approach, Lietuvos matematikos rinkinys, 55, 73-78.

Жилинскиене, Демирбилек (2015): Inga Žilinskienè, Muhammet Demirbilek, Use of geogebra in primary math education in Lithuania: An exploratory study from teachers' perspective, Informatics in Education, 14(1), 127-142.

Кларк, Рош, Мичел (2011): Doug Clarke, Anne Roche, Annie Mitchell, OneTo-One Student Interviews Provide Powerful Insights and Clear Focus for the Teaching of Fractions in the Middle Years, Fractions: Teaching for Understanding, 23-41.

Лавица (2007): Zsolt Lavicza, Factors Influencing the Integration of Computer Algebra Systems into University-Level Mathematics Education, International Journal for Technology in Mathematics Education, 14(3), 121-129.

Лазић, Маричић, Милинковић (2015): Бојан Лазић, Сања Маричић, Јасмина Милинковић, Пропедевтичко учење разломака засновано на интеграцији садржаја у

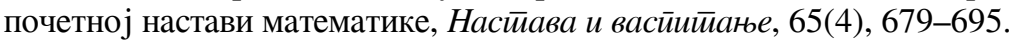

Љајко (2014): Еуген Љајко, Уйицај Geogebra-е на йреgавање и учење анали-

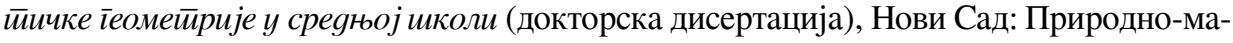
тематички факултет.

Мајерек (2014): Dariusz Majerek, Application of Geogebra for teaching mathematics, Advances in Science and Technology, 8(24), 51-54.

Нуњес, Брајант, Хари, Прецлик (2006): Terezinha Nunes, Peter Bryant, Jane Hurry, Ursula Pretzlik, Fractions: difficult but crucial in mathematics learning, Teaching and Learning Research Programme, 13.

Причард (2010): Chris Pritchard, How to Cut a Slice of Cheesecake in Half, Mathematics in School, 39(4), 21-23.

Пун (2017): Kin Keung Poon, Learning fraction comparison by using a dynamic mathematics software - GeoGebra, International Journal of Mathematical Education in Science and Technology, 49(3), 469-479. doi:10.1080/0020739x.2017.1404649

Радовановић, Карић (2011): Vesna Radovanović, Jasmina Karić, Stavovi nastavnika prema primeni informacionih i komunikacionih tehnologija u školama za gluve i nagluve, Specijalna edukacija i rehabilitacija, 10(1), 37-48.

Радовић (2013): Slaviša Radović, Teaching Materials "Surface Area of Geometric Figures" Created Using the Software Package GeoGebra, European Journal of Contemporary Education, 4(2), 72-80. 
Тамби, Еу (2013): Noorbaizura Thambi, Leong Kwan Eu, Effect of students' achievement in fractions using GeoGebra, SAINSAB, 16, 97-106.

Турлингс, Купман, Ден Брок, Пепин (2019): Marieke Thurlings, Maaike Koopman, Perry den Brok, Birgit Pepin, Portraying primary fraction teaching: A variety of mathematical richness, pedagogic strategies, and use of curriculum materials, International Journal of Education in Mathematics, Science and Technology (IJEMST), 7(2), 170-185. DOI:10.18404/ijemst.552452

Фу Лок, Ху Тонг, Таи Чау (2017): Nguyen Phu Loc, Duong Huu Tong, Phan Thai Chau, Identifying the concept "fraction" of primary school students: The investigation in Vietnam, Academic Journals, 12(8), 531-539.

Џонсон, Брофи (2011): Paddy Johnson, Tim Brophy, GeoGebra Workbook 6: Radian Measure, Fractions \& Optimisation, Regional Centre for Excellence in Mathematics Teaching and Learning.

\section{Milan P. Milikić}

Nenad R. Vulović

\section{Aleksandra M. Mihajlović}

University of Kragujevac

Faculty of Education in Jagodina

Department for Didactics and Methodology

\section{GEOMETRIC INTERPRETATION OF FRACTIONS USING GEOGEBRA EDUCATIONAL SOFTWARE}

Summary: Fractions are one of the basic mathematical concepts in the lower grades of primary school. Considering student's level of cognitive thinking and their need for concrete teaching, multiple visual representations offer better understanding of fraction concepts. In the first part of the paper some models of dividing the whole into two halves using the GeoGebra software were presented. The second part of the paper presented the results of a study aimed to investigate to what extent educational software is present in teaching mathematics in lower grades of primary school. The attitudes of class teachers towards the use of educational software were analysed as well. The sample consisted of 108 teachers from the territory of the Republic of Serbia. The results have shown that a large percent of respondents did not completely understand the term educational software. In addition to this, the research results indicate that, although a majority of respondents believe educational software increases the quality of students' knowledge, a very small part of them had a chance to get acquainted with the benefits of using GeoGebra software in teaching.

Keywords: fractions, educational software, GeoGebra, half, teachers. 